\title{
Effects of low temperature on the condition of flight muscles and flight propensity in a water strider, Aquarius paludum (Heteroptera: Gerridae)
}

\author{
Tetsuo HARADA*, Shizuna INOUE and Masao WATANABE \\ Laboratory of Environmental Physiology, Faculty of Education, Kochi, University, Kochi 780-8520, Japan
}

Key words. Gerridae, Aquarius paludum, water strider, chilling, indirect flight muscles, flight propensity, overwintering

\begin{abstract}
Effects of chilling on dispersal characteristics of adults of the water strider, Aquarius paludum were studied in the laboratory. The condition of flight muscles was monitored during overwintering under natural conditions in Kochi $\left(33^{\circ} \mathrm{N}\right)$, Japan. For diapause adults kept under $12 \mathrm{~h}$ light- $12 \mathrm{~h}$ dark $(12 \mathrm{~L}: 12 \mathrm{D})$, chilling at $7^{\circ} \mathrm{C}$ for $48 \mathrm{~h}$ from the 70 th day after emergence caused lower Supercooling Point (SCP) and promoted higher flight propensity than among gerrids not exposed to chilling. For reproductive adults kept under $15.5 \mathrm{~L}: 8.5 \mathrm{D}, 91.3 \%$ of 34 adults retained well-developed flight muscles 1 week after the chilling (49 days after emergence), whereas $67.6 \%$ of 49 adults which had not been exposed to $7^{\circ} \mathrm{C}$ histolysed their flight muscles. According to diapause development, part of the adults which had well developed flight muscles histolysed them during December to February. Chilling in fall might trigger dispersal to overwintering sites by diapause adults and, that in spring could inhibit histolysis of flight muscles by overwintered reproductive adults.
\end{abstract}

\section{INTRODUCTION}

Water striders (Heteroptera: Gerridae) inhabit permanent and/or temporary water surfaces, and show dispersal polymorphism in temperate zones (Andersen, 1973; Vepsäläinen, 1978; Calabrase, 1979; Zera et al., 1983; Spence, 1989; Harada et al., 2000). In general, stability of usual habitat is inversely related to dispersal ability of a given species. Dispersal ability of a population is represented by the proportion of individuals which have well developed wings (Vepsäläinen, 1978; Roff, 1986; Spence, 1989; Fujisaki, 1994) and also by flight propensity (Harada et al., 1988). Aquarius paludum inhabits both permanent and temporary water surfaces (Harada et al., 2000), and adults fly throughout their life cycle even in reproductive season when forty percent of adults have long wings and retain dispersal ability only in the case of poor food supply (Inoue \& Harada, 1997). Diapause and overwintering adults and overwintered reproductives can be exposed to low temperatures, respectively, in late fall and winter and early spring in the field.

Overwintering adults of the third diapause generation emerge in October or November in Kochi, Japan (Harada \& Numata, 1993). The first experience of low temperature can be a cue for them to migrate to overwintering sites on land. In the spring overwintered adults may histolyse flight muscles and lay many eggs after migrating to new habitats (Harada, 1998). However, they might be exposed to low temperature by chance in early spring after migrating to the new habitats. In that case, they must keep their flight muscles intact because they will have limited nutritional resources for reproduction until warmer temperatures arrive. Exposure to low temperatures, however, might serve as a cue to delay histolysis of flight muscles.
During winter diapause, flight muscles are histolysed for survival in the Colorado beetle, Leptinotarsa decemlineata (Danks, 1987) and the tropical beetle Stenotarsus rotundus (Wolda \& Denlinger, 1998). The nutritional reserves of flight muscles also might be allocated to survival in winter in $A$. paludum, but there are no data about this point.

This study aims, first, at examining the effects of exposure to low temperature on the condition of flight muscles and flight propensity of diapause and reproductive adults of the water strider, A. paludum. Adults were reared under short-days and long-days in the laboratory. We also monitored flight muscle condition of overwintering adults under natural conditions from October to April in Kochi $\left(33^{\circ} \mathrm{N}\right)$, Japan.

\section{MATERIALS AND METHODS}

\section{Effects of exposure to $7^{\circ} \mathrm{C}$ on dispersal characteristics} (Fig. 1)

Reproductive and long-winged adults were collected from a pond in Kochi, Japan $\left(33^{\circ} \mathrm{N}\right)$ in late summer 2000 , and kept under $15.5 \mathrm{~h}$ light $8.5 \mathrm{~h}$ dark at $20 \pm 2^{\circ} \mathrm{C}$, which are conditions promoting reproduction (Harada et al., 2000). Eggs laid by these adults and juveniles that hatched from them were reared at $20 \pm$ $2^{\circ} \mathrm{C}$ under $15.5 \mathrm{~L}: 8.5 \mathrm{D}$ (long-days) or $12 \mathrm{~L}: 12 \mathrm{D}$ (short-days). Half of adults emerging under each photoperiod were chilled at $7^{\circ} \mathrm{C}$ for $48 \mathrm{~h}$, starting from the 40 th day after emergence, and then returned to $20 \pm 2^{\circ} \mathrm{C}$. The other half of adults were not exposed to the $7^{\circ} \mathrm{C}$ but kept at $20 \pm 2^{\circ} \mathrm{C}$. Flight propensity, supercooling point (SCP) and condition of flight muscles were examined 1 week after the end of chilling. The state of the indirect flight muscles was classified as follows [scheme simplified from Fairbairn \& Desranleau (1987)]:

Rank 3. Indirect flight muscles large, fibrous and reddish, corresponding with "normal" in Fairbairn \& Desranleau (1987).

\footnotetext{
* Corresponding author. E-mail: haratets@cc.kochi-u.ac.jp
} 


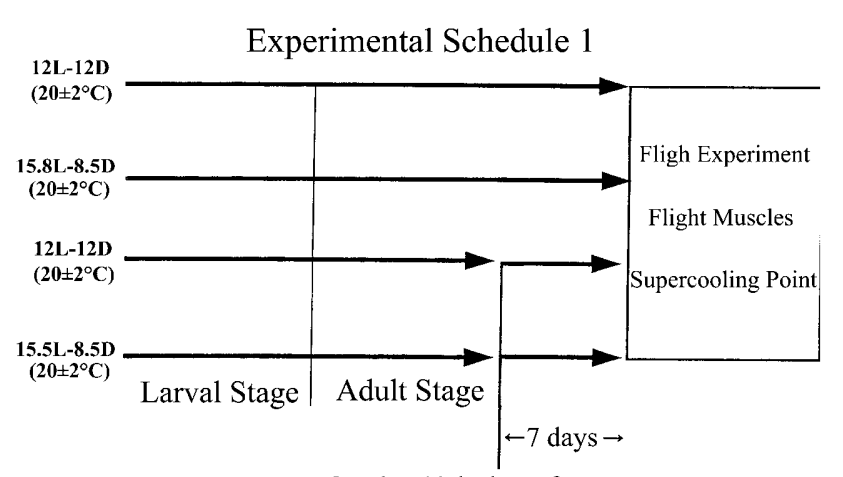

On the 40th day after emergence chilling at $7^{\circ} \mathrm{C}$ for $48 \mathrm{~h}$

Fig. 1. Experimental schedule for examining the effects of chilling at $7^{\circ}$ for $48 \mathrm{~h}$ on dispersal characteristics and supercooling point (SCP) of a water strider, Aquarius paludum.

Rank 2. Flight muscles small, soft, and white, corresponding with "teneral: advanced" or "histolysed: early"

Rank 1. Muscle fibers not visible, corresponding with "histolysed: advanced or complete" or "teneral: early"

A bronze-nickel thermocouple was used for measuring of SCP. The thermocouple was attached on the ventral surface of thorax with an adhesive tape. The body with the thermocouple was fixed to the inside wall of the heat-insulating box made of expanded plastics. The box was sealed out and put into the freezer where temperature was decreased to $-40^{\circ} \mathrm{C}$ from $20^{\circ} \mathrm{C}$ by about $1^{\circ} \mathrm{C}$ per $1 \mathrm{~min}$. inside the box. The flight experiment was designed as follows (basically after Harada et al., 1997). A white paper was placed on the bottom of a cylindrical transparent case $(30 \mathrm{~cm}$ in diameter, height $15 \mathrm{~cm})$, and an adult water strider was transferred from the rearing case into a transparent cylindrical enclosure $(5 \mathrm{~cm}$ in diameter) placed at the center of the box. Infra-red light warmed the bottom of the case to maintain the temperature at $32 \pm 2{ }^{\circ} \mathrm{C}$. The individual insect was illuminated from the side for $30 \mathrm{sec}$. with a beam of blue light (about $3400 \mathrm{Lx}$ ) from a tungsten lamp through a glass filter. Administered together, the heat and light stimuli trigger flight in individuals able to fly. The enclosure was then picked up and the bug was given $1 \mathrm{~min}$. to move. After the first observation period, a bug was again stimulated by the blue light and observed for an additional minute. Most bugs that flew did so for less than $0.5 \mathrm{sec}$, stopped flying and folded their wings. Flight propensity for each insect was represented by the flight index (FI), which was calculated as follows: $\mathrm{FI}=1$ when wingopening was induced only once for the $3 \mathrm{~min}$. in total; FI $=2$ if the bug actually flew only once; FI $=5$ if the bug actually flew twice and opened wings once for the $3 \mathrm{~min}$.

\section{Monitoring the condition of flight muscles during overwin- tering}

More than 100 overwintering adults were collected in fall 2000 from a water way in Kochi and kept under natural conditions in the open through winter to the next spring. They were kept in a transparent aquarium $(70 \mathrm{~cm} \times 50 \mathrm{~cm} \times 50 \mathrm{~cm})$ the bottom of which was half water and half soil. On the soil, fallen leaves were put for overwintering sites. The aquarium was under shade during daytime in a completely open terrace of a faculty building. Twelve or eighteen adults were taken from the reared adults on each date of December 25, 2000, February 15, 2001 and March 15, 2001 and SCP and flight muscle condition were examined. These data were compared with those from
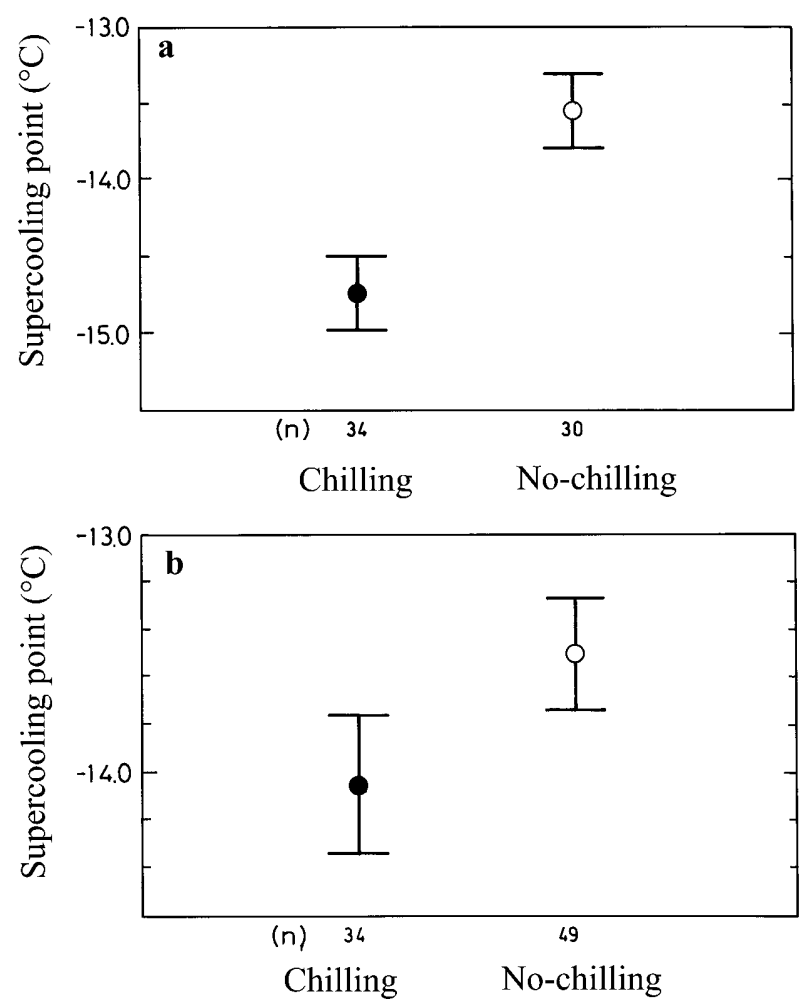

Fig. 2. Effects of chilling at $7^{\circ} \mathrm{C}$ on supercooling point (SCP) of a water strider, Aquarius paludum reared under $12 \mathrm{~h}$ light : $12 \mathrm{~h}$ dark (a) or $15.5 \mathrm{~h}$ light : $15 \mathrm{~h}$ dark (b) through larval and adult stages.

adults collected from the field October 20, 1997, December 10, 1997 and April 25, 1998.

\section{RESULTS}

\section{Effects of chilling on dispersal characteristics}

All of the adults kept under $15.5 \mathrm{~L}: 8.5 \mathrm{D}$ carried matured oocytes, while those held under $12 \mathrm{~L}: 12 \mathrm{D}$ entered diapause and had no mature oocytes on the 49th day after emergence. Supercooling points of adults exposed to $7^{\circ} \mathrm{C}$ for $48 \mathrm{~h}$ averaged $-14.1^{\circ} \mathrm{C}$ under the long-days and $-14.7^{\circ} \mathrm{C}$ under the short-days. These values were significantly lower than those measured for the control groups $\left(-13.5^{\circ} \mathrm{C}\right.$ under the long-days: $-13.6^{\circ} \mathrm{C}$ under the short-days) (Mann-Whitney U-test in the longdays and in the short-days: $\mathrm{P}<0.01$ ) (Fig. 2a, b). Under the short-days, flight behavior was triggered in $91 \%$ of the diapause adults that had experienced the chilling, but in only $23 \%$ of those which had not been exposed to $7^{\circ} \mathrm{C}$ (Mann-Whitney U-test for flight index: $\mathrm{P}<0.01, \chi^{2}$ test for the proportion of specimens in which flights were triggered: $\mathrm{P}<0.01$ ) (Figs 3 a,b \& 4).

Under the long-days, $91.2 \%$ of 34 reproductive adults had well-developed and reddish flight muscles 1 week after the end of chilling, on the 49th day after emergence, whereas only $32.4 \%$ of 49 adults have kept their flight muscles when they had not been chilled $\left(\chi^{2}\right.$ test: $\left.\mathrm{P}<0.01\right)$ (Fig. 5). Under short-days, more than $95 \%$ of adults retained well-developed and reddish flight muscles regardless of whether they had been chilled or not. 

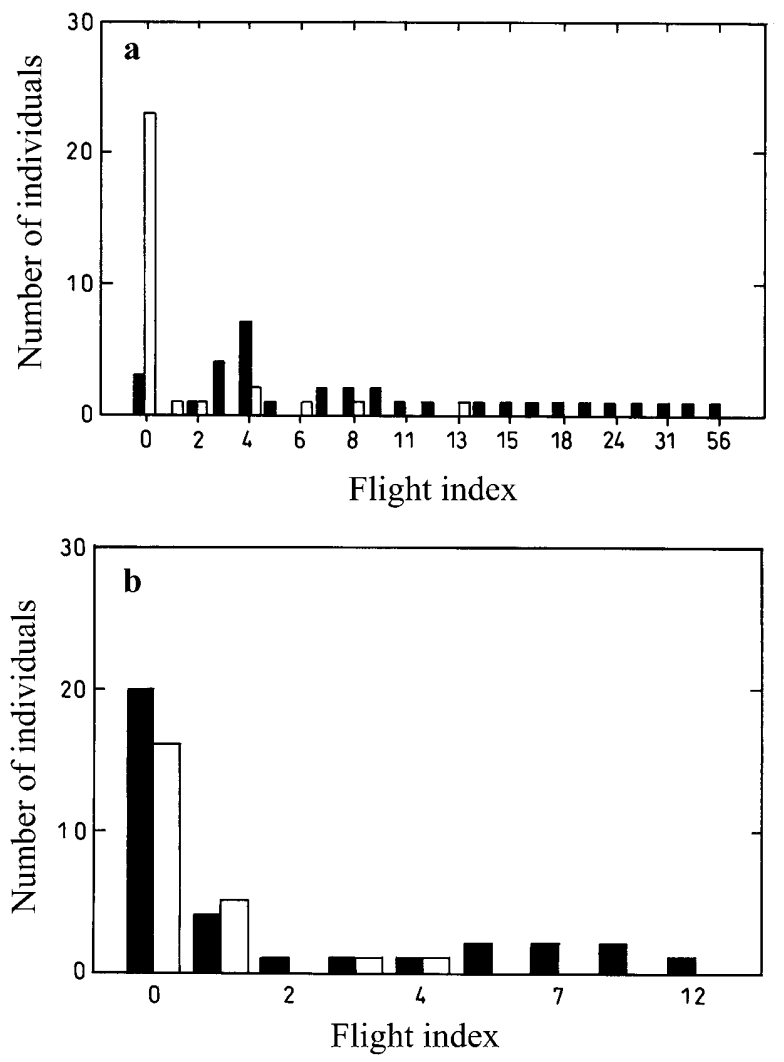

Fig. 3. Effects of chilling at $7^{\circ} \mathrm{C}$ on flight propensity of a water strider, Aquarius paludum reared under $12 \mathrm{~h}$ light $: 12 \mathrm{~h}$ dark (a) or $15.5 \mathrm{~h}$ light : $8.5 \mathrm{~h}$ dark (b) through larval and adult stages.

(Closed: individuals exposed to $7^{\circ} \mathrm{C}$; open: those which had not experienced the chilling)

\section{Monitoring the condition of flight muscles and SCP during overwintering}

Proportion of the adults which had well-developed flight muscles was only $20 \%$ in October, but $83 \%$ in December. However, it fell again to $17-25 \%$ in February and March. The proportion appears to have risen a little bit to $32 \%$ in April ( $\chi^{2}-$ test of multiple samples from October to April: $\mathrm{P}<0.001$ ) (Fig. 6). Supercooling points

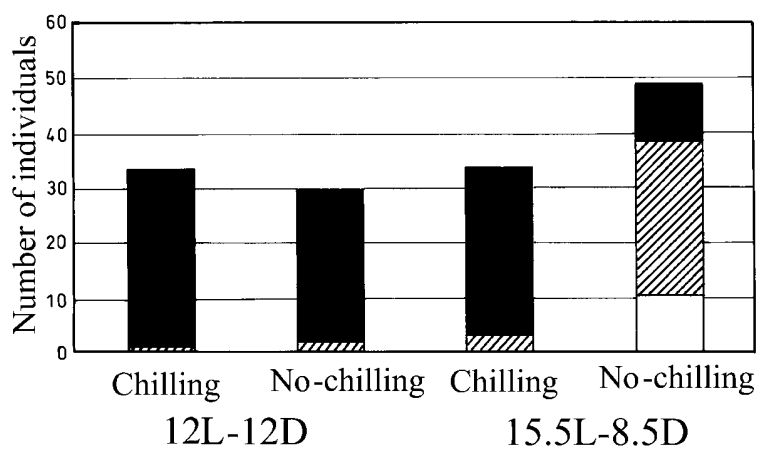

Fig. 5. Effects of chilling at $7^{\circ} \mathrm{C}$ on the condition of flight muscles in a water strider, Aquarius paludum reared under $12 \mathrm{~h}$ light $: 12 \mathrm{~h}$ dark or $15 \mathrm{~h}$ light $: 8.5 \mathrm{~h}$ dark through larval and adult stages. Conditions of flight muscles: well developed - closed, on the way of development or histolysis - hachured, complete histolysis - open (Inoue \& Harada 1997).

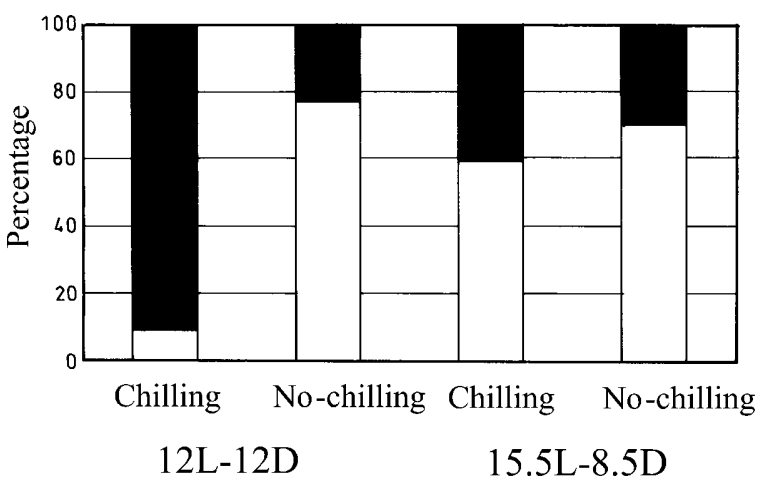

Fig. 4. Effects of chilling at $7^{\circ} \mathrm{C}$ on the proportion of specimens (closed) of which flights or opening wings were triggered during the flight experiment on a water strider, Aquarius paludum. Specimens were illuminated by a beam of blue light (about $3400 \mathrm{Lx}$ ) from a tungsten lamp through a glass filter (Harada et al., 1987).

in February and March $\left(-14.0 \pm 3.0^{\circ} \mathrm{C}\right)$ were significantly lower than those in December $\left(-9.0 \pm 1.7^{\circ} \mathrm{C}\right)$ (MannWhitney U-test: $\mathrm{P}<0.01)$. Cold acclimation in winter might cause the decreased SCP.

\section{DISCUSSION}

In Kochi, A. paludum is trivoltine (Harada \& Numata, 1993), with part of the second generation and all of the third generation overwintering as adults in reproductive diapause (Harada, 1993). When these adults emerge in October or November early morning low temperatures could trigger flight to overwintering sites on land.

When A. paludum was kept under $15.5 \mathrm{~L}: 8.5 \mathrm{D}$ at $20 \pm$ $2{ }^{\circ} \mathrm{C}$ through larval and adult stages, histolysis of flight muscles occurred 20-50 days after emergence (Harada et al., 1997). In 25-30 days, half of adults had histolysed flight muscles, and all had done so before the 50th day after emergence (Harada et al., 1997). In the present study, more than $50 \%$ of adults histolysed flight muscles by the 40th day after emergence when reproductive adults were exposed to $7^{\circ} \mathrm{C}$. Therefore more than $40 \%$ of the adults seem to have regenerated their flight muscles, during the one week after chilling, because $91 \%$ of the reproductive adults had well-developed flight muscles on

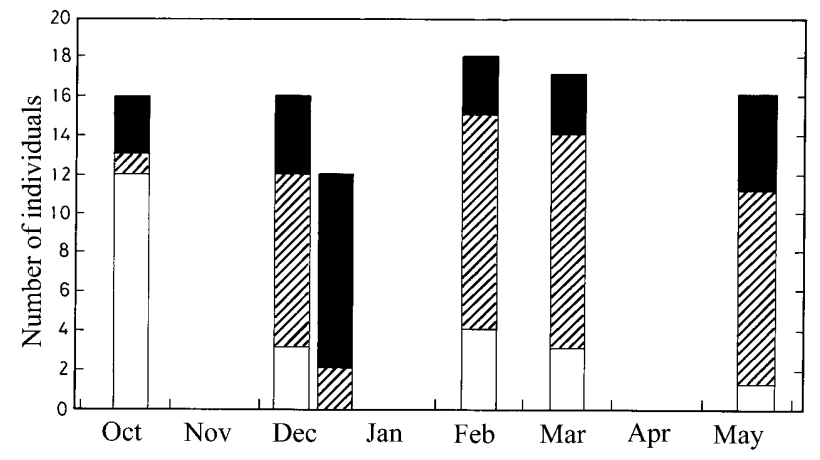

Fig. 6. Seasonal change in the condition of flight muscles of a water strider, Aquarius paludum from fall to the next spring. Flight muscles were examined on Oct 20, Dec 10, Dec 25, Feb 15, Mar 15 and April 25, 1997-1998 or 2000-2001.

For explanations see Fig. 5 
the 49th day. Second generation adults of $A$. paludum reproduce once in September and then enter reproductive diapause (Harada, 1993). During reproduction, flight muscles seem to be histolysed just after the active migration to new temporary habitats in rainy season of September (Harada, 1992; Kawamura \& Harada, unpublished). Exposure to low temperatures in late fall may stimulate second generation adults to regenerate flight muscles for moving to overwintering sites on land. Overwintered adults of $A$. paludum also histolyse flight muscles in spring (Harada, 1998). It is possible that low temperature during early spring could postpone flight muscle histolysis until it becomes warm enough for reproduction.

Hauser (1985) reported that wax was secreted externally on the cuticle in another water strider, Gerris odontogaster and suggested that this had a protective function during overwintering. Fig. 6 suggests that flight muscle histolysis could occur during overwintering after moving to overwintering sites in accordance with diapause development. The resources derived from the histolysis could perhaps be used for producing wax on the body and for basic metabolic requirement in association with overwintering in $A$. paludum.

During overwintering, SCP decreases in relation to diapause development in $A$. paludum. This lowered SCP doubtlessly reflects cold acclimation in winter (Fig. 2). Supercooling points for diapause adults held under $12 \mathrm{~L}$ : 12D (Fig. 2a) were lowered more by chilling than they were in reproductive adults held under $15.5 \mathrm{~L}: 8.5 \mathrm{D}$ (Fig. 2b). Diapause in $A$. paludum might be linked to cold hardening system as in other insect species (Denlinger \& Lee, 1998). The supercooling point of $A$. paludum is much lower than the lethal temperature, which is located at about $-3^{\circ} \mathrm{C}$ (Harada et al., unpublished). Like many other insect species (Lee \& Denlinger, 1985; Knight et al., 1986; Bale, 1987), A. paludum might be susceptible to chilling injury that could lead to death. Whether there is or not some correlation between supercooling point and ability to survive low temperature should be analysed in the future.

ACKNOWLEDGEMENTS. This work was financially supported by The Japanese Ministry of Education, Sciences, Culture, Arts and Sports (Grant No. 10740361; Grant No. 11794001: 1999-2002) to T. Harada. Thanks are also due to Professor John R. Spence, University of Alberta for his valuable scientific comments and linguistic check.

\section{REFERENCES}

ANDERSEN N.M. 1973: Seasonal polymorphism and developmental changes in organs of flight and reproduction in bivoltine pondskaters (Hem.: Gerridae). Entomol. Scand. 4: $1-20$.

BALE J.S. 1987: Insect cold hardiness: Freezing and supercooling - an ecophysiological perspective. J. Insect Physiol. 33: 899-908.

Calabrese D.M. 1979: Pterygomorphism in 10 nearctic species of Gerris. Am. Midl. Nat. 101: 61-68.
DANKS H. 1987: Insect Dormancy: An Ecological Perspective. Biological Survey of Canada (Terrestrial Arthropods), Ottawa, p. 24

Denlinger D.L. \& Lee R.E. Jr. 1998: Physiology of cold sensitivity. In: Hallman G.J. \& Denlinger D.L. (eds): Temperature Sensitivity in Insects and Application in Integrated Pest Management. Westview Press, Colorado \& Oxford, pp. 57-95.

Fatrbarrn D.J. \& Desranleau L. 1987: Flight threshold, wing muscle histolysis, and alary polymorphism: correlated traits for dispersal tendency in the Gerridae. Ecol. Entomol. 12: $13-24$.

FunsaKi K. 1994: Evolution of dispersal polymorphisms in insects: a close examination of Roff's theory. Jap. J. Appl. Entomol. Zool. 38: 231-244. [in Japanese]

HARADA T. 1992: The oviposition process in two direct breeding generations in a water strider, Aquarius paludum (Fabricius). J. Insect Physiol. 38: 687-692.

HARADA T. 1993: Reproduction by overwintering adults of water strider, Aquarius paludum (Fabricius). Zool. Sci. 10: 313-319.

HARADA T. 1998: To fly or not to fly: response of water striders to drying out of habitat. Ecol. Entomol. 23: 370-376.

Harada T. \& Numata H. 1993: Two critical daylengths for the determination of wing forms and the induction of adult diapause in the water strider, Aquarius paludum. Naturwissenschaften 80: 430-432.

Harada T., TABUChI R. \& Koura J. 1997: Migratory syndrome in the water strider, Aquarius paludum (Heteroptera: Gerridae) reared in high versus low nymphal densities. Eur. J. Entomol. 94: 445-452.

Harada T., Inoue T., Morioka H. \& Dor K. 1988: Comparative studies on migratory syndrome of two water striders, Aquarius paludum (Fabricius) and Gerris latiabdominis Miyamoto. Proc. 6th Eur. Congr. Entomol. 1: 239.

Harada T., Inoue T., Ono I., Kawamura N., Kishi M., Dor K., Inoue S. \& Hodkova M. 2000: Endocrine, ecophysiological and ecological aspects of seasonal adaptations in a water stride, Aquarius paludum (a mini review). Entomol. Sci. 3: $157-165$.

HAUSER R. 1985: Ein Diapausesekret bei Wasserläufern (Hemiptera: Gerridae). Mitt. Schweiz. Entomol. Ges. 58: 511-525.

Inoue T. \& HARADA T. 1997: Lengthening photophase reduces dispersal ability in a water strider, Aquarius paludum (F.). Naturwissenschaften 84: 306-308.

Knight J.D., Bale J.S., Franks F., Mathias S.F. \& Baust J.G. 1986: Insect cold hardiness: supercooling points and prefreeze mortality. Cryo-Letters 7: 194-203.

Lee R.E. Jr. \& Denlinger D.L. 1985: Cold tolerance in diapausing and non-diapausing stages of the flesh fly, Sarcophaga crassipalpis. Physiol. Entomol. 10: 309-315.

RoFF D.A. 1986: Evolution of wing dimorphism in insects. Evolution 40: 1009-1020.

SPENCE J.R. 1989: The habitat templet and life history strategies of pond skaters (Heteroptera: Gerridae): reproductive potential, phenology, and wing dimorphism. Can. J. Zool. 67: 2432-2447.

VEPSÄLÄINEN K. 1978: Wing dimorphism and diapause in Gerrids; determination and adaptive significance. In: Dingle $\mathrm{H}$. (ed.): Evolution of Insect Migration and Diapause. SpringerVerlag, New York. pp. 218-253.

Wolda H. \& Denlinger D.L. 1998: Diapause in a large aggregation of a tropical beetle. Ecol. Entomol. 9: 217-230.

Zera A.J., InNes D.J. \& Saks M.E. 1983: Genetic and environmental determination of wing polymorphism in the water strider Limnoporus canaliculatus. Evolution 37: 513-522.

Received August 20, 2002; revised June 18, 2003; accepted August 5, 2003 